\title{
Postural costs of performing cognitive tasks in non-coincident reference frames
}

\author{
E. V. Fraizer $\cdot$ Suvobrata Mitra
}

Published online: 21 November 2007

(C) Springer-Verlag 2007

\section{Erratum to: Exp Brain Res}

\section{DOI 10.1007/s00221-007-1163-1}

The first name of the second author was misspelt. The correct name is as follows: Suvobrata Mitra

The online version of the original article can be found under doi:10.1007/s00221-007-1163-1.

\section{E. V. Fraizer $(\bowtie)$}

Department of Psychology,

Institute of Applied Cognitive Science,

University of Warwick, Coventry CV4 7AL, UK

e-mail: E.V.Fraizer@warwick.ac.uk; evfraizer@fsmail.net

\section{S. Mitra}

Department of Psychology,

Institute of Applied Cognitive Science,

University of Warwick, Coventry, UK 